\title{
Development of dissolution test method for a telmisartan/ amlodipine besylate combination using synchronous derivative spectrofluorimetry
}

\author{
Panikumar Durga Anumolu1,*, Sirisha Neeli², Haripriya Anuganti², Sathesh Babu Puvvadi \\ Ranganatham ${ }^{2}$, Subrahmanyam Chavali Venkata Satya ${ }^{2}$
}

\begin{abstract}
${ }^{1} R \&$ D Center, Jawaharlal Nehru Technological University, Department of Pharmaceutical Sciences, Hyderabad, Andhra Pradesh, India ${ }^{2}$ Gokaraju Rangaraju College of Pharmacy, Osmania University, Hyderabad, Andhra Pradesh, India
\end{abstract}

\begin{abstract}
The dissolution process is considered an important in vitro tool to evaluate product quality and drug release behavior. Single dissolution methods for the analysis of combined dosage forms are preferred to simplify quality control testing. The objective of the present work was to develop and validate a single dissolution test for a telmisartan (TEL) and amlodipine besylate (AML) combined tablet dosage form. The sink conditions, stability and specificity of both drugs in different dissolution media were tested to choose a discriminatory dissolution method, which uses an USP type-II apparatus with a paddle rotating at $75 \mathrm{rpm}$, with $900 \mathrm{~mL}$ of simulated gastric fluid (SGF without enzymes) as the dissolution medium. This dissolution methodology provided good dissolution profiles for both TEL and AML and was able to discriminate changes in the composition and manufacturing process. To quantify both drugs simultaneously, a synchronous first derivative spectrofluorimetric method was developed and validated. Drug release was analyzed by a fluorimetric method at $458 \mathrm{~nm}$ and $675 \mathrm{~nm}$ for AML and TEL, respectively. The dissolution method was validated as per ICH guidance.
\end{abstract}

Uniterms: Combined dosage forms/quality control. Dissolution test/combined dosage forms. Telmisartan. Amlodipine besylate. Spectrofluorimetry/quantification analysis.

O processo de dissolução é considerado como uma importante ferramenta in vitro para avaliar a qualidade do produto e o comportamento de liberação do fármaco. Prefere-se um ensaio único de dissolução para formas farmacêuticas contendo associação de fármacos pela simplificação dos testes de controle de qualidade. O objetivo do presente trabalho foi desenvolver e validar um teste de dissolução único para forma farmacêutica comprimidos contendo telmisartana (TEL) e besilato de anlodipino (AML) associados. Condições "sink", estabilidade e especificidade de ambos os fármacos nos diferentes meios de dissolução foram avaliadas para selecionar um método de dissolução discriminatório, que utiliza um aparato do tipo II da USP, com pás girando a $75 \mathrm{rpm}$ e $900 \mathrm{~mL}$ de fluido gástrico simulado (SGF sem enzima) como o meio de dissolução. Estas condições proporcionaram bons perfis de dissolução para ambos, TEL e AML, sendo capaz de discriminar as mudanças na composição e processo de fabricação. Para quantificar os dois fármacos simultaneamente, um método de fluorescência derivada sincronizado foi desenvolvido e validado. A quantidade de fármaco liberado foi analisada pelo método fluorimétrico em 458 e $675 \mathrm{~nm}$ para a AML e TEL, respectivamente. O método de dissolução foi validado de acordo com a orientação da ICH.

Unitermos: Forma farmacêutica com associação/controle de qualidade. Teste de dissolução/forma farmacêutica com associação. Telmisartana. Besilato de anlodipino. Espectrofluorimetria/análise quantitativa.

*Correspondence: Panikumar Anumolu Durga. Gokaraju Rangaraju College of Pharmacy, Department of Pharmaceutical Analysis, Hyderabad, 500090 Andhra Pradesh, India. E-mail: panindrapharma@yahoo.co.in 


\section{INTRODUCTION}

Drug dissolution testing an important analytical technique to evaluate product quality, to assess drug release behavior and to discriminate changes in the formulation and manufacturing process (Kulkarni et al., 2012). The strategy to determine the solubility and permeability properties of drugs uses a biopharmaceutical classification system to classify drugs into four basic groups (Amidon et al., 1995). The development of a dissolution method for a drug product with limited water solubility and combinations of drugs has been a challenge for both the pharmaceutical industry and regulatory agencies (Soni et al., 2008; Dressman et al., 1998; Oliveira et al., 2009). Currently, there is increased demand for biorelevant dissolution media, which have the ability to discriminate changes in the formulation and manufacturing process (He et al., 2004; Panikumar et al., 2012; Menegola et al., 2007). In vitro dissolution media is formulated to be biorelevant, as it should be able to serve as a surrogate of the in vivo environment. In vitro dissolution media are made biorelevant by adding various levels of bio-salts, lecithin and fatty acids (Galia et al., 1998). A single dissolution method for the analysis of multiple API active components in combinations present in a dosage form is preferred to simplify quality control testing procedures (Vignaduzzo et al., 2010; Huang et al., 2011; Panikumar et al., 2013; Zongyun et al., 2011).

Telmisartan (TEL) (Figure 1A), chemically known as 4'-[(1,4'-dimethyl-1-2'-propyl[2,6'-bi-1Hbenzimidazol]-1'yl)methyl]-[1,1'-biphenyl]-2-carboxylic acid, is a angiotensin-II $\left(\mathrm{AT}_{1}\right)$ receptor antagonist used in the treatment of hypertension and myocardial infarction. Amlodipine besylate (AML) (Figure 1B), chemically known as 3-ethyl-5-methyl 2-(2-amino ethoxy methyl)4-(2-chloro phenyl)-1,4-dihydro-6-methyl pyridine-3,5dicarboxylate benzene sulfonate, is a calcium channel blocker used in the treatment of hypertension and angina pectoris (Anthony, David, Brian, 2004). TEL and AML have been formulated in a fixed-dose combination used in the treatment of hypertension. To the best of our knowledge, no single dissolution test has been reported for TEL and AML in a combined tablet dosage form. Therefore, the objective of the present investigation was to develop and validate a single discriminating dissolution test method for TEL and AML in a combined tablet dosage form. A literature survey revealed that a few analytical methods are available for the simultaneous quantification of TEL and AML by spectrophotometry (Pratap et al., 2012) and high performance liquid chromatography (Mhaske et al., 2012; Kottai et al., 2010). Chromatographic methods are complex, as they require expensive instrument setup and skilled operators (Basavaiah, Raghu, Vinay, 2012). Spectrophotometry methods are unsuitable for the evaluation of drugs in multi-component analysis because of the lack of specificity (Mark, Workman Jr., 2003).

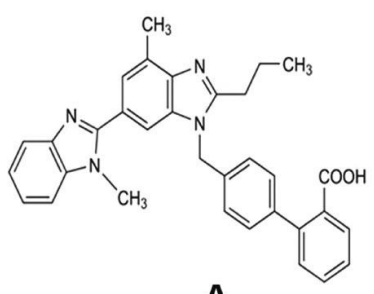

A

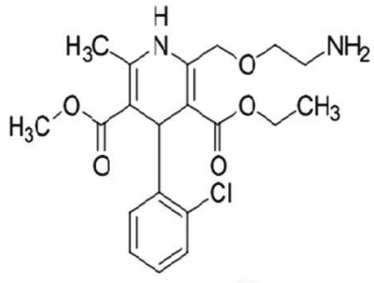

B
FIGURE 1- Chemical structure of telmisartan (A) and amlodipine besylate (B).

Spectrofluorimetry has assumed a major role in drug analysis because of its greater sensitivity and selectivity than absorption spectrophotometry (Gomez-Hens, 1991). The synchronous first derivative spectrofluorimetry technique is superior in terms of sensitivity, spectral discrimination, and provides more reliable identification of chemical species in multi-component analysis without interference from formulation excipients and components of the dissolution media (Andrade et al., 2010; Belal et al., 2011; Ei-wassef et al., 2009). Therefore, we developed and validated a simple synchronous first derivative spectrofluorimetric method for the simultaneous quantification of TEL and AML in dissolution samples.

\section{MATERIAL AND METHODS}

\section{Material}

All chemicals and reagents were of analytical grade. Telmisartan (TEL) and amlodipine besylate were gift samples from Dr. Reddy's Laboratories Ltd, Hyderabad. Telsartan-AM and Sartel-AM formulations (TEL $40 \mathrm{mg}$ and AML $5 \mathrm{mg}$ ) were purchased from local pharmacies. Hydrochloric acid, ortho-phosphoric acid, potassium dihydrogen orthophosphate, sodium hydroxide and sodium chloride were purchased from SD Fine Chemicals Ltd, Mumbai, India; sodium lauryl sulfate (SLS), Tween 80 , cetrimide, lecithin and sodium taurocholate were purchased from Himedia Ltd, Mumbai, India.

\section{Instrumentation}

The fluorescence spectra and measurements were recorded using a Shimadzu (Japan) RF-5301 PC 
spectrofluorophotometer, equipped with a $150 \mathrm{~W}$ Xenon arc lamp. A $1 \mathrm{~cm}$ quartz cell was used, connected to RFPC software. The instrument was operated both at low and high sensitivity with the excitation and emission slit width set at $5 \mathrm{~nm}$. A dissolution apparatus (Electro lab TDT-08L), analytical balance (Shimadzu AUX 220, Japan), pH meter (Elico), tablet compression machine (Lab Press, CIP Machineries, Ahmedabad, India) and hardness tester (Secor, Hyderabad, India) were used for the study.

\section{Analytical method}

Standard solutions of TEL and AML were diluted appropriately with 1 molar (M) hydrochloric acid $(\mathrm{HCl})$ to obtain solutions containing TEL $(4 \mu \mathrm{g} / \mathrm{mL})$ and AML $(4 \mu \mathrm{g} / \mathrm{mL})$. The fluorescence spectra of these diluted solutions were scanned in the spectral range of 350 to $800 \mathrm{~nm}$. The normal spectra of TEL and AML were transformed to corresponding synchronous first derivative spectra in the range of 350 to $800 \mathrm{~nm}$ and overlapped. The first derivative spectrum of TEL had zero intensity at $458 \mathrm{~nm}$, whereas AML gave a significant derivative response. The derivative spectrum of AML had zero intensity at $675 \mathrm{~nm}$, whereas TEL gave a significant derivative response. Therefore, $458.0 \mathrm{~nm}$ was selected for the estimation of AML and $675 \mathrm{~nm}$ was selected for the estimation of TEL in the co-formulation and in vitro dissolution studies.

\section{Dissolution test conditions}

Dissolution testing of TEL (40 mg) and AML (5 $\mathrm{mg}$ ) bulk drug-filled capsules (12 units) was performed using a paddle-type USP tablet dissolution apparatus, in $900 \mathrm{~mL}$ of various buffers, such as $0.1 \mathrm{M} \mathrm{HCl}$, acetate buffer ( $\mathrm{pH} 2.7$ and 4.7), phosphate buffer ( $\mathrm{pH} 3.6 / 5.6 / 6.8$ and 7.4) and like simulated gastric fluid without enzymes (SGF); modified fasted and fed state intestinal fluids (MFaSSIF and MFeSSIF) and blank fasted and fed state intestinal fluids (FaSSIF and FeSSIF) at $50 \mathrm{rpm}$ and at $37 \pm 0.5{ }^{\circ} \mathrm{C}$ for $60 \mathrm{~min}$. Aliquots of $5.0 \mathrm{~mL}$ were withdrawn at $5 \mathrm{~min}$ interval up to $60 \mathrm{~min}$, and replaced with an equal volume of fresh medium to maintain sink conditions. At the end of the test, the withdrawn samples were filtered, diluted with $1 \mathrm{M} \mathrm{HCl}$ and quantified by the developed and validated spectrofluorimetric method. The dissolution studies were conducted three times using four capsules in each of the media (12 units). The amount of dissolved drugs was computed from the respective calibration curves and then plotted against time. The media in which highest drug release occurred for the TEL and AML bulk drugs was the medium chosen for the in vitro dissolution studies of the tablet dosage form (Telsartan-AM and Sartal-AM).

\section{Validation of the dissolution method}

The method was validated by the analysis of specificity, linearity, accuracy and precision as per ICH guidelines (2005).

The specificity of the proposed method was evaluated through the analysis of a placebo solution, which was prepared with the common excipients (lactose, starch, microcrystalline cellulose, magnesium stearate, titanium dioxide and talc) of the pharmaceutical formulation. Thus, the mixture of inert components was prepared in their usual concentrations employed in tablets (concentrations were determined based on the Handbook of Pharmaceutical Excipients and calculated for the medium weight of the contents) (Raymond, Paul, Sian, 2007). The developed method was applied in order to check if any component of the formulation could generate a response or generate an emission band similar to the drugs.

Linearity was determined by constructing the plot between analyte intensity $v s$. concentration to calculate the regression line for standard dilutions of 4-14 (TEL) and 1-6 $\mu \mathrm{g} / \mathrm{mL}$ (AML) using the linear least squares methodology.

The precision of the method was determined by intra-day precision and inter-day precision variations as per ICH guidelines. The intra-day precision and inter-day precision were assessed after subjecting six tablets to the dissolution test conditions, on the same day and on three different days respectively. The \% RSD was calculated.

The accuracy was carried out by adding known amount of standard drug at 80,100 and $120 \%$ of the nominal assay of TEL and AML to the placebo sample in the dissolution media and then subjected to the proposed dissolution method. The experiment was conducted in triplicate. The percentage recovery and percentage relative standard deviation (\%RSD) were calculated for each concentration.

\section{Stability determination}

Sample solutions were prepared in the optimized dissolution media and at the same dissolution test conditions. Aliquot samples were collected initially and at $24 \mathrm{~h}$ intervals for 2 days and analyzed by the proposed analytical method. The drug concentrations were compared after 0,24 and $48 \mathrm{~h}$. 


\section{RESULTS AND DISCUSSION}

\section{Development of dissolution method}

The selection of a dissolution test method was based on screening studies using a USP type II apparatus at a paddle speed of 50/75 rpm. The selection of a dissolution medium to provide adequate solubility and stability of both TEL and AML was critical for the selected dissolution method. The $\log \mathrm{P}$ values of TEL and AML were 6.66 and 3.0, respectively, indicating the poor water solubility and lipophilic character of both drugs. TEL is soluble in strong acid and basic media, but strong basic media are not suitable as dissolution media because of the gastrointestinal $\mathrm{pH}$ range of 1.0-7.4. AML solubility was similar in all buffered media ( $\mathrm{pH} 1.2-7.5)$. The screening results showed that the dissolution rates of both bulk drugs were higher in simulated gastric fluid (SGF) media ( $\mathrm{pH}$ 1.2) than other media (Table I), due to the interaction between lone pairs of electrons on nitrogen atoms and the ionizable groups present in TEL and $\mathrm{AML}$ with $\mathrm{NaCl}, \mathrm{HCl}$ molecules present in SGF media (prepared as per USP-2007, without enzymes, consisting of 2 gm sodium chloride, $0.2 \mathrm{M}$ hydrochloric acid to adjust $\mathrm{pH}$ to 1.2 and volume make upto $1000 \mathrm{~mL}$ ). Thus, this media was useful for the quality control testing of both drugs in tablets. The $\mathrm{pH}$ of the dissolution medium was 1.2, i.e. within the range of gastrointestinal tract $\mathrm{pH}$ levels, and therefore mimicked the gastrointestinal tract environment (biorelevant). This assay was designed to provide information for pharmaceutical researchers involved in the development of new biorelevant dissolution media and in predicting the in vivo performance of poorly soluble drugs. Therefore, the selected dissolution test conditions were: USP type II apparatus at a paddle speed of $75 \mathrm{rpm}$ in $900 \mathrm{~mL}$ of simulated gastric fluid ( $\mathrm{pH}$ 1.2).

\section{In vitro dissolution studies from tablet dosage forms}

Dissolution studies on Telsartan-AM and Sartel-AM tablets were performed under the optimized dissolution test conditions. These results are shown in Figures 2 and 3 , and reveal that more than $90 \%$ of both TEL and AML were released from the two products.

\section{Stability studies}

Both TEL and AML were found to be stable under dissolution test conditions and the measured derivative absorbance of the initial time and after 24 and $48 \mathrm{~h}$ was similar. There was no evidence of degradation of the drugs
TABLE I - Screening study results for dissolution of TEL (40 mg) and AML ( $5 \mathrm{mg}$ ) bulk drug using a USP type II apparatus at $50 \mathrm{rpm}$, temperature $37^{\circ} \mathrm{C} \pm 0.5$ for $60 \mathrm{~min}$

\begin{tabular}{lcc}
\hline \multirow{2}{*}{ Dissolution media } & \multicolumn{2}{c}{ \% Drug release } \\
& Mean \pm RSD ( $=12)$ \\
\cline { 2 - 3 } & TEL & AML \\
\hline 0.1 N Hydrochloric acid & $73.57 \pm 0.30$ & $100.50 \pm 1.92$ \\
Acetate buffer, pH 2.7 & $7.11 \pm 0.28$ & $94.88 \pm 0.35$ \\
Acetate buffer, pH 3.6 & $12.03 \pm 1.30$ & $97.37 \pm 4.66$ \\
Acetate buffer pH 4.7 & $14.91 \pm 2.41$ & $100.98 \pm 0.03$ \\
Phosphate buffer, pH 5.6 & $13.81 \pm 1.22$ & $98.86 \pm 2.05$ \\
Phosphate buffer, pH 6.8 & $19.73 \pm 0.62$ & $98.88 \pm 4.03$ \\
Phosphate buffer, pH 7.4 & $9.27 \pm 0.30$ & $71.89 \pm 6.18$ \\
$\begin{array}{l}\text { SGF (simulated gastric fluid } \\
\text { without enzymes) }\end{array}$ & $79.17 \pm 2.12$ & $98.18 \pm 5.44$ \\
$\begin{array}{l}\text { BFaSSIF (Blank fasted state } \\
\text { simulated intestinal fluid) }\end{array}$ & $11.89 \pm 0.825$ & $95.42 \pm 2.58$ \\
$\begin{array}{l}\text { BFeSSIF (Blank fed state } \\
\text { simulated intestinal fluid) }\end{array}$ & $5.08 \pm 0.445$ & $98.42 \pm 2.88$ \\
$\begin{array}{l}\text { MFaSSIF (Modified fasted } \\
\text { state simulated intestinal fluid) }\end{array}$ & $11.48 \pm 0.45$ & $99.42 \pm 2.59$ \\
$\begin{array}{l}\text { MFeSSIF (Modified fed state } \\
\text { simulated intestinal fluid) }\end{array}$ & $5.17 \pm 0.33$ & $100.0 \pm 1.10$ \\
\hline
\end{tabular}

\begin{tabular}{lll}
\hline Telsartan-AM Tablets & & \\
\hline $50 \mathrm{rpm}$, SGF media & $86.66 \pm 0.29$ & $99.28 \pm 0.01$ \\
$75 \mathrm{rpm}$, SGF media & $96.86 \pm 1.22$ & $98.28 \pm 0.02$ \\
\hline Sartel-AM Tablets & & \\
\hline $50 \mathrm{rpm}$, SGF media & $88.03 \pm 1.20$ & $99.05 \pm 2.03$ \\
$75 \mathrm{rpm}$, SGF media & $93.81 \pm 1.59$ & $99.01 \pm 2.05$ \\
\hline
\end{tabular}

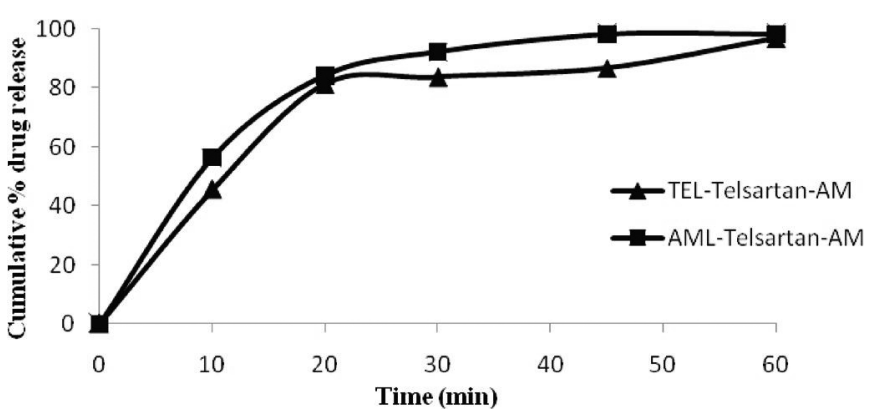

FIGURE 2 - In vitro dissolution profile of Telsartan-AM tablets in SGF media at $75 \mathrm{rpm}(\mathrm{n}=12)$.

under the dissolution test conditions, indicating that the solutions were stable for more than $48 \mathrm{~h}$.

\section{Discriminatory power of the dissolution method}

The discriminatory power of the dissolution method was determined by manufacturing tablets under different 




FIGURE 3- In vitro dissolution profile of Sartel-AM tablets in $\mathrm{SGF}$ media at $75 \mathrm{rpm}(\mathrm{n}=12)$.

TABLE II - Data obtained from stability studies

\begin{tabular}{lccc}
\hline \multicolumn{4}{c}{$\%$ Amount of drug found } \\
\hline Drug & initial time & after $24 \mathrm{~h}$ & after 48 h \\
\hline TEL & 98.01 & 98.05 & 99.05 \\
AML & 99.06 & 100 & 99.06 \\
\hline
\end{tabular}

conditions and checking the dissolution behavior in the presence of the proposed dissolution test conditions. The effect of tablet hardness $\left(5 \mathrm{~kg} / \mathrm{cm}^{2} v s .8 \mathrm{~kg} / \mathrm{cm}^{2}\right)$ and the disintegrant (with disintegrant $v s$. without disintegrant) are shown in Figures 4 and 5, revealing that dissolution rate of both drugs was slightly faster for tablets with less hardness and with a disintegrant. Therefore, this dissolution method has the ability to discriminate changes in the composition and manufacturing process. The dissolution profile data were also compared mathematically using the similarity fit factor $\left(\mathrm{f}_{2}\right)$.

$$
f_{2}=50 \cdot \log \left\{\left[1+\frac{1}{n} \sum_{t=1}^{n} w_{t}\left(R_{t}-T_{t}\right)^{2}\right]^{-0.5} \times 100\right\}
$$

If $\mathrm{f}_{2}$ is less than 50 , then two dissolution profiles are considered dissimilar. The similarity increases as the $\mathrm{f}_{2}$ value increases above 50 and approaches 100 (FDA 1997). The similarity factor $f_{2}$ was calculated from the dissolution profile, using five points for telmisartan and three points for amlodipine besylate. Among these, one point was found to indicate more $85 \%$ of drug release.
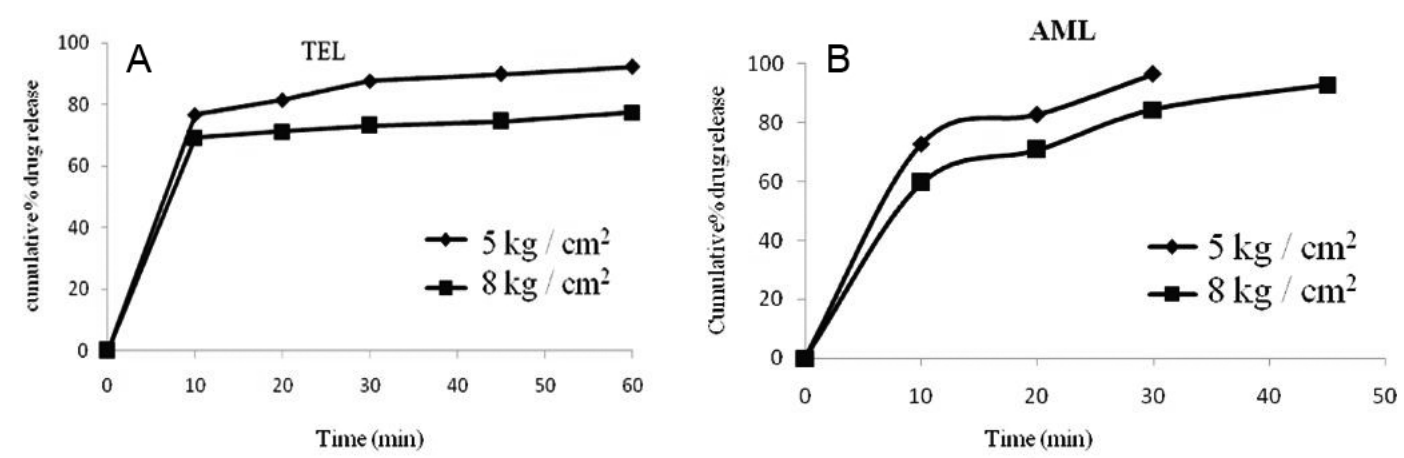

FIGURE 4 - Comparison of dissolution profiles of TEL/AML tablets manufactured with different hardness.(A) Profile for TEL and (B) for AML.
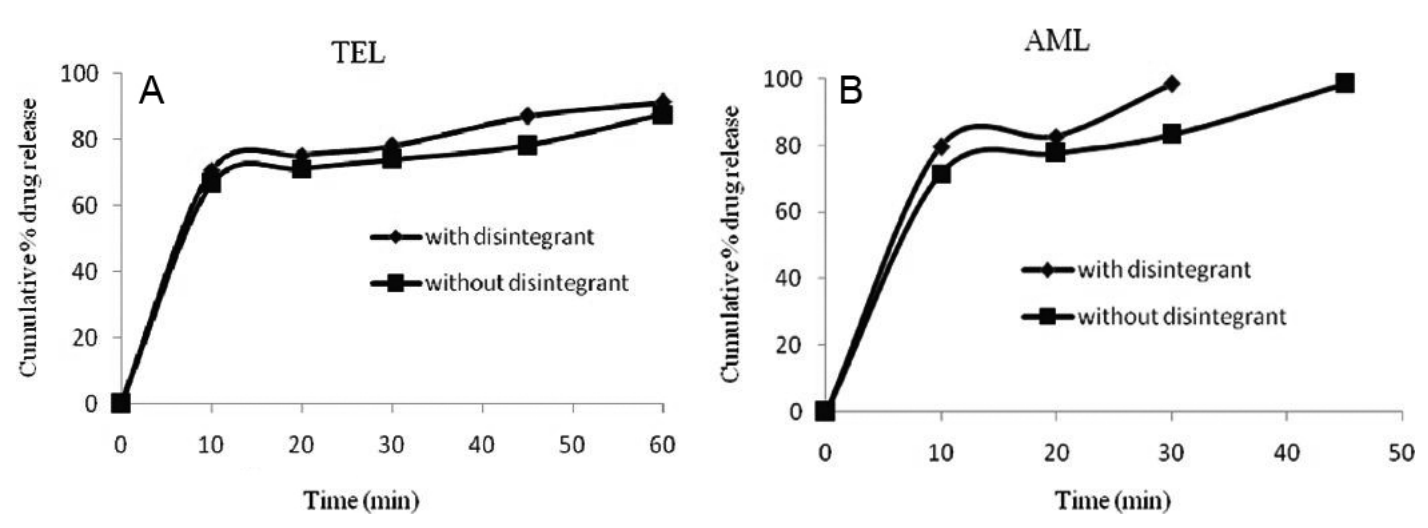

FIGURE 5- Comparison of dissolution profiles of TEL/AML tablets manufactured with and without a disintegrant.(A) Profile for TEL and (B) for AML. 
Table III lists the $\mathrm{f}_{2}$ values used for the comparison of the dissolution profiles for each of the process parameters evaluated. These results confirm that the dissolution test procedure has discriminating power regarding variation in the composition and manufacturing process.

TABLE III - Similarity factor $\left(\mathrm{f}_{2}\right)$ for dissolution profiles of tablets with different parameters

\begin{tabular}{ccc}
\hline & $\mathrm{f}_{2}$ Value & \\
\hline $\begin{array}{c}\text { Process } \\
\text { parameter }\end{array}$ & $\begin{array}{c}\text { Tablets with } \\
\text { hardness of 5 } \mathrm{kg} / \\
\mathrm{cm}^{2} \text { vs. 8 kg/cm }\end{array}$ & $\begin{array}{c}\text { Tablets containing } \\
\text { disintegrant vs. no } \\
\text { disintegrant }\end{array}$ \\
\hline TEL & 44.47 & 63.14 \\
AML & 46.14 & 49.21 \\
\hline
\end{tabular}

\section{Method validation}

\section{Specificity}

The synchronous fluorescence derivative spectra of the placebo, TEL and AML in the dissolution medium are shown in Figure 6. Perusal of the figure shows that there was no interference from the excipients in the tablets and dissolution medium with the derivative response of either of the drugs (TEL and AML) at their respective analytical wavelengths. Therefore, the proposed method is specific.

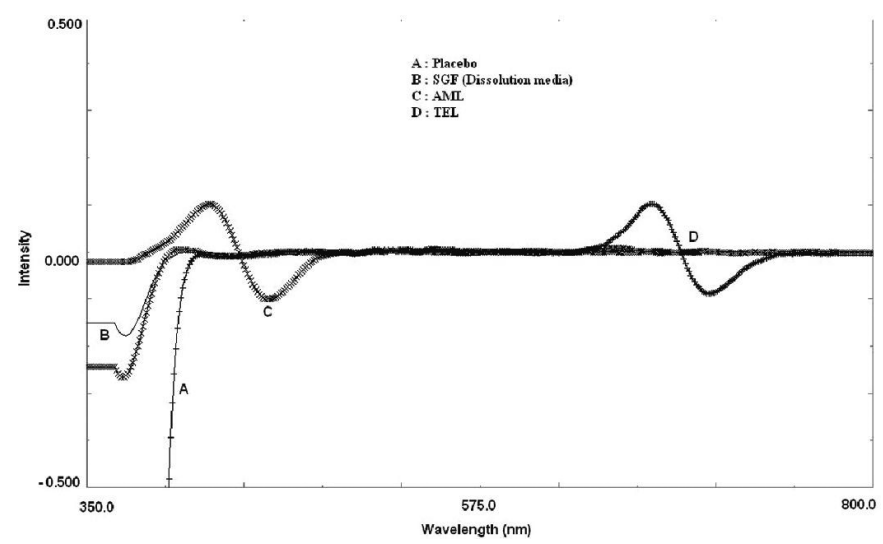

FIGURE 6 - Synchronous first order derivative spectrum of placebo (A), blank dissolution medium (B), AML (C) and TEL (D).

\section{Linearity}

The linearity was evaluated by the least square regression method. The responses for TEL at $675 \mathrm{~nm}$ were found to be linear in the concentration range of 4-14 $\mu \mathrm{g} / \mathrm{mL}$, with a correlation coefficient (r) value of 0.997 . Similarly, the responses for AML at $458 \mathrm{~nm}$ were linear in the concentration range of $1-6 \mu \mathrm{g} / \mathrm{mL}$, with a correlation coefficient (r) value of 0.999 . The results indicate a good linear relationship between the derivative response and concentration. Linearity plots are shown in Figure 7.

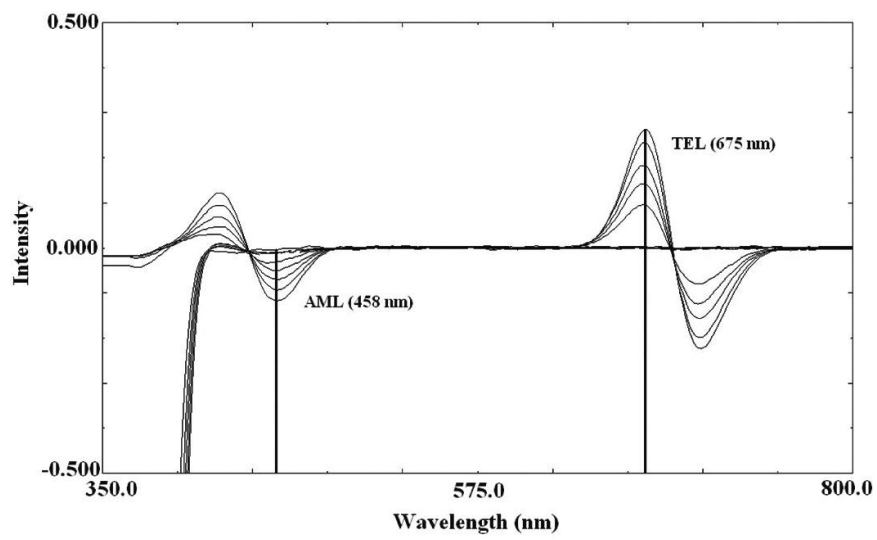

FIGURE 7 - First derivative synchronous linearity spectrum of amlodipine besylate (AML) and telmisartan (TEL).

\section{Precision}

The percent relative standard deviation values for intra and inter day precision studies were found to be less than 2 and there was no significant difference observed between the intra- and inter-day values, which indicates that the proposed method was reproducible and precise. The results are reported in Table IV.

\section{Accuracy}

Accuracy shows the agreement between the standard value and the observed value. The accuracy results of the proposed dissolution method are reported in Table V. Percent recovery was from $97.0-99.0 \%$ and percent relative standard values were less than 2 ; this signifies that the dissolution method is accurate for its intended use.

\section{CONCLUSION}

The discriminating and dissolution test developed and validated for TEL/AML tablets was considered satisfactory. The best conditions optimized for dissolution testing for TEL/AML tablets were: $900 \mathrm{~mL}$ of simulated gastric fluid (SGF without enzymes), a paddle-type apparatus, stirring speed of $75 \mathrm{rpm}$, a temperature of 37 ${ }^{\circ} \mathrm{C} \pm 0.5$ and collection time of $60 \mathrm{~min}$. The dissolution studies for TEL and AML combination tablets in the proposed dissolution media were found to be better, because of their discriminating power, utility as a surrogate of the gastrointestinal tract environment (biologically relevant). In addition, these studies provide information for pharmaceutical researchers involved in the development of new biorelevant dissolution media and predicting the in vivo performance of poorly soluble drugs. The 
TABLE IV - Precision data for the proposed dissolution method

\begin{tabular}{lcccccccc}
\hline \multirow{2}{*}{ Product } & \multicolumn{4}{c}{ TEL } & \multicolumn{3}{c}{ AML } \\
\cline { 2 - 9 } & \multicolumn{2}{c}{ Intra-day (\%) } & \multicolumn{2}{c}{ Inter-day (\%) } & \multicolumn{2}{c}{ Intra-day (\%) } & \multicolumn{2}{c}{ Inter-day (\%) } \\
\cline { 2 - 9 } & Mean \pm SD & \%RSD & Mean \pm SD & \%RSD & Mean \pm SD & \%RSD & Mean \pm SD & \%RD \\
\hline Telsartan-AM & $96.86 \pm 1.07$ & 1.11 & $97.28 \pm 0.78$ & 0.80 & $98.28 \pm 0.11$ & 0.11 & $99.98 \pm 0.99$ & 0.99 \\
Sartel-AM & $93.81 \pm 0.59$ & 0.63 & $99.10 \pm 0.98$ & 0.98 & $99.01 \pm 1.05$ & 1.06 & $98.89 \pm 1.25$ & 1.264 \\
\hline
\end{tabular}

TABLE V - Results for accuracy for the proposed dissolution method

\begin{tabular}{lccccc}
\hline \multirow{2}{*}{ Analyte } & \multirow{2}{*}{ \% level of recovery } & \multicolumn{5}{c}{ Amount (m) } \\
\cline { 2 - 6 } & & Added & Recovered & \%Recovery & \%RSD \\
\hline TEL & 80 & 32 & 31.56 & 98.62 & 1.10 \\
& 100 & 40 & 38.82 & 97.05 & 0.89 \\
& 120 & 48 & 47.52 & 99.0 & 1.24 \\
\hline AML & 80 & 4 & 3.90 & 97.5 & 1.02 \\
& 100 & 5 & 4.85 & 97.0 & 0.98 \\
& 120 & 6 & 5.89 & 98.16 & 0.85 \\
\hline
\end{tabular}

results obtained from validation show that the proposed dissolution method was scientifically sound. These advantages encourage the routine use of the developed dissolution method in the quality control analysis of TEL and AML in tablet dosage forms.

\section{ACKNOWLEDGMENTS}

The authors are thankful to the management of Gokaraju Rangaraju College of Pharmacy for providing necessary facilities and infrastructure to carry out this research work.

\section{REFERENCES}

AMIDON, G.L.; LENNERNÄS, H.; SHAH, V.P.; CRISON, J.R. A theoretical basis for a biopharmaceutic drug classification: the correlation of in vitro drug product dissolution and in vivo bioavailability. Pharm. Res., v.12, n.3, p.413-420, 1995.

ANDRADE-EIROA, A.; DE-ARMAS, G.; ESTELA, J.M.; CERDA, V. Critical approach to synchronous spectrofluorimetry. Trends Anal. Chem., v.29, n.8, p.885901, 2010.

ANTHONY, C.M.; DAVID, M.O.; BRIAN, W. Clarke's analysis of drugs and poisons. 3.ed. London: Pharmaceutical Press, 2004. p.629, 1601.
BASAVAIAH, K.; RAGHU, M.S.; VINAY, K.B. Simple and rapid spectrophotometric assay of levocetirizine in pharmaceuticals through charge-transfer complexation using chloranilic acid and 2,3-dichloro-5,6-dicyanoquinone as $\pi$-acceptors. Bull. Chem. Soc. Ethiop., v.26, n.3, p.319328,2012

BELAL, F.; EL-BRASHY, A.; EL-ENANY, N.; TOLBA, M. Conventional and first derivative synchronous fluorometric determination of ethamsylate in pharmaceutical preparations and biological fluids. Application to stability studies. $J$. Floresec., v.21, n.4, p.1371-1384, 2011.

DRESSMAN, J.B.; AMIDON, G.L.; REPPAS, C.; SHAH, V.P. Dissolution testing as prognostic tool for oral drug absorption: immediate release dosage forms. Pharm. Res., v.15, n.1, p.11-22, 1998. .

EI-WASSEF, D.R.; EI-SHEEBINY D.T.; ABU-EI-ENEIN M.A.; EI-ASHRY S.M. Simultaneous determination of labetalol and furosemide by first derivative synchronous spectrofluorimetry. J. Fluoresc, v. 19, n.5, p.817-828, 2009.

FOOD AND DRUG ADMINISTRATION. FDA. Guidance for industry: immediate release solid dosage forms: in vitro dissolution testing and in vivo bioequivalence documentation. Rockville: FDA, 1997. p.1-21. 
GALIA, E.; NICOLAIDES, E.; HORTER, D.; LÖBENGER, R.; REPPAS, C.; DRESSMAN, J.B. Evaluation of various dissolution media for predicting in vivo performance of class I and II drugs. Pharm. Res., v.15, n.5, p.698-705, 1998.

GOMEZ-HENS, A. Modern aspects of fluorimetry as applied to clinical chemistry. Pure Appl. Chem., v.63, n.8, p.10831088, 1991.

HE, Z.; ZHONG, D.; CHEN, X.; LIU, X.; TANG, X.; ZHAO, L. Development of a dissolution medium for nimodipine tablets based on bioavailability evaluation. Eur. J. Pharm. Sci., v.21, n.4, p.487-491, 2004.

INTERNATIONAL CONFERENCE ON HARMONIZATION. ICH. Harmonized tripartite guideline. Validation of analytical procedures: text and methodology Q2B. Rockville: ICH,1996. p.1-10.

KOTTAI, R.; SANKHLA, A.; GUPTA, S.H.; SMITH, A.A.; MANAVALAN, R. Development and validation of a reversed phase HPLC method for simultaneous determination of amlodipine and telmisartan in pharmaceutical dosage form. J. Appl. Chem. Res., v.12, p.43-52, 2010.

KULKARNI, A.P.; SHAHNAWAZ, M.; ZAHEER, Z.; DEHGHAN, M.H.G. Development and validation of a dissolution method for pioglitazone tablets. Dissolut. Technol., v.19, n.4, p.36-45, 2012.

MENEGOLA, J.; STEPPE, M.; SCHAPOVAL, E.E. Dissolution test for citalopram in tablets and comparison of in vitro dissolution profiles. Eur. J. Pharm. Biopharm., v.67, n.2, p.524-530, 2007.

MHASKE, R.A.; GAROLE, D.J.; MHASKE, A.A.; SAHASRABUDHE, S. RP-HPLC method for simultaneous determination of amlodipine besylate, valsartan, telmisartan, hydrochlorothiazide and chlorthalidone: application to commercially available drug products. Int. J. Pharm. Sci. Res., v.3, n.1, p.141-149, 2012.

MARK, H.; WORKMAN JR., J. Derivative in spectroscopy. Part I - The behavior of the derivative. Spectroscopy, v.18, n.4, p.32-33, 2003.

OLIVEIRA, E.; AIEVEDO, R; BONEILIO, R.; OLIVEIRA, D.B.; REBEIRO, G.P.; ARAVJO, M.B. Dissolution test optimization for meloxicam in the tablet pharmaceutical form. Braz. J. Pharm. Sci., v.45, n.1, p.67-73, 2009.
PANIKUMAR, A.D.; SUNITHA, G.; VENKAT RAJU, Y.; SATHESH BABU, P.R.; SUBRAHMANYAM, C.V.S. Development of biorelevant and discriminating method for dissolution of efavirenz and its formulations. Asian J. Pharm. Clin. Res., v.5, n.3, p.220-223, 2012.

PANIKUMAR, A. D.; SUNITHA, G.; VENKAT RAJU, Y.; SATHESH BABU, P.R.; SUBRAHMANYAM, C.V.S. Development of dissolution test method for drotaverine hydrochloride/mefenamic acid combination using derivative spectrophotometry. Trop. J. Pharm. Res., v.12, n.2, p.227-232, 2013.

PRATAP, Y.P.; MANISH, A.R.; SWATI, U.K.; RESHMA, B.K. Simultaneous spectrophotometric estimation of amlodipine besylate and telmisartan in tablet dosage form. Der Pharmacia Chemica, v.4, n.2, p.725-730, 2012

RAYMOND, C.R.; PAUL, J.S.; SIAN, C.O. Handbook of pharmaceutical excipients. 2.ed. Chicago, London: Pharmaceutical Press, American Pharmacists Association, 2007. p.132, 385,725.

SONI, T.; NAGDA, E.; GANDHI, T.; CHOTAI, N.P. Development of discriminating method for dissolution of aceclofenac marketed formulations. Dissolut. Technol., v.15, n.2, p.31-34, 2008.

VIGNADUZZO, S.E.; CASTELLANO, P.; KAUFMAN, T.S. Development and validation of a dissolution test for meloxicam and pridinol mesylate from combined tablet formulation. India J. Pharm. Sci., v.72, n.2, p.197-203, 2010 .

UNITED STATES PHARMACOPEIA.USP 30: The National formulary: NF 25: by authority of the United States Pharmacopeia Convention prepared by the council of experts and its expert committees. Rockville: United States Pharmacopeia Convention,2007.v.2.p.1092.

ZONGYUN, H.; RUBEN, L.; ROBERT, F.; ANNEFRANCOISE, A.; ALYSON, S.; DENIS, S. Development of a single in-vitro dissolution method for a combination trilayer tablet formulation of clopidogrel and pravastatin. Dissolut. Technol., v.18, n.2, p.12-19, 2011.

Received for publication on $21^{\text {st }}$ May 2013 Accepted for publication on $21^{\text {st }}$ January 2014 